NOS for Quality Assessment of Non-randomized studies

\title{
Metabolic Syndrome Components Correlation with Colorectal Neoplasms: A Systematic Review and a Meta-analysis (Supplementary data)
}

\author{
Salah Eddine El Herrag ${ }^{1}$, Youssouf Traoré ${ }^{1}$, Méghit Boumediène Khaled ${ }^{1,2}$ * \\ 1 Department of Biology, Faculty of Natural and Life Sciences, Djillali Liabes University, PO Box 89, Sidi-Bel-Abbes (22000), Algeria
}

NEWCASTLE-OTTAWA QUALITY ASSESSMENT SCALE FOR CASE CONTROL STUDIES

\section{SELECTION}

1) Is the case definition adequate?

a) yes, with independent validation $(*)$

b) yes, e.g. record linkage or based on self-reports

c) no description

2) Representativeness of the cases

a) consecutive or obviously representative series of cases $\left(^{*}\right)$

b) potential for selection biases or not stated

3) Selection of Controls

a) community controls $\left({ }^{*}\right)$

b) hospital controls

c) no description

4) Definition of Controls

a) no history of disease (endpoint) ${ }^{*}$ )

b) no description of source

\section{COMPARABILITY}

1) Comparability of cases and controls on the basis of the design or analysis

a) study controls for ___ (Select the most important factor) (*)

b) study controls for any additional factor $\left(^{*}\right)$ (This criterion could be modified to indicate specific control for a second important factor)

\section{EXPOSURE}

1) Ascertainment of exposure

a) secure record (e.g. surgical records) $\left(^{*}\right)$

b) structured interview where blind to case/control status $\left(^{*}\right)$

c) interview not blinded to case/control status d) written self-report or medical record only e) no description

2) Same method of ascertainment for cases and controls

a) yes (*)

b) no

3) Non-Response rate

a) same rate for both groups $(*)$

b) non respondents described

c) rate different and no designation

NEWCASTLE-OTTAWA QUALITY ASSESSMENT SCALE FOR COHORT STUDIES

\section{SELECTION}

1) Representativeness of the exposed cohort

a) truly representative of the average _ (describe) in the community $\left(^{*}\right)$

b) somewhat representative of the average ___ in the community $\left(^{*}\right)$

c) selected group of users e.g. nurses, volunteers

d) no description of the derivation of the cohort

2) Selection of the non-exposed cohort

a) drawn from the same community as the exposed cohort (*)

b) drawn from a different source

c) no description of the derivation of the non-exposed cohort

3) Ascertainment of exposure

a) secure record (e.g. surgical records) (*)

b) structured interview $(*)$

c) written self-report

d) no description 
4) Demonstration that outcome of interest was not present at start of study

a) yes $\left(^{*}\right)$

b) no

\section{COMPARABILITY}

1) Comparability of cohorts on the basis of the design or analysis

a) study controls for ___ (select the most important factor) $\left(^{*}\right)$

b) study controls for any additional factor $(*)$ (This criterion could be modified to indicate specific control for a second important factor)

\section{OUTCOME}

1) Assessment of outcome

a) independent blind assessment $(*)$

b) record linkage $(*)$

c) self-report

d) no description

2) Was follow-up long enough for outcomes to occur

a) yes (select an adequate follow up period for outcome of interest) (*)

b) no

3) Adequacy of follow up of cohorts

a) complete follow up - all subjects accounted for (*)

b) subjects lost to follow up unlikely to introduce bias - small number lost - > \% (select an adequate \%) follow up, or description provided of those lost) (*)

c) follow up rate < _ \% (select an adequate \%) and no description of those lost

d) no statement

NEWCASTLE-OTTAWA QUALITY ASSESSMENT SCALE ADAPTED FOR CROSS-SECTIONAL STUDIES I

\section{SELECTION}

1) Representativeness of the sample

a) Truly representative of the average in the target population (*) (all subjects or random sampling)

b) Somewhat representative of the average in the target population (*) (non-random sampling)

c) Selected group of users

d) No description of the sampling strategy

2) Sample size

a) Justified and satisfactory (*)

b) Not justified

3) Non-respondents

a) Comparability between respondents and non-respondents' characteristics is established, and the response rate is satisfactory (*)

b) The response rate is unsatisfactory, or the comparability between respondents and non-respondents is unsatisfactory

c) No description of the response rate or the characteristics of the responders and the non-responders

4) Ascertainment of the exposure (risk factor)

a) Validated measurement tool (**)

b) Non-validated measurement tool, but the tool is available or described $(*)$

c) No description of the measurement tool

\section{COMPARABILITY}

1) The subjects in different outcome groups are comparable, based on the study design or analysis. Confounding factors are controlled.

a) The study controls for the most important factor (select one) $\left(^{*}\right)$

b) The study control for any additional factor $\left(^{*}\right)$

\section{OUTCOME}

\section{1) Assessment of the outcome}

a) Independent blind assessment $(*)$

b) Record linkage $\left(^{*}\right)$

c) Self report. d) No description

2) Statistical test

a) The statistical test used to analyze the data is clearly described and appropriate, and the measurement of the association is presented, including confidence intervals and the probability level ( $P$ value) $\left(^{*}\right)$

b) The statistical test is not appropriate, not described or incomplete

\footnotetext{
${ }^{1}$ The scale was adapted from the NOS for case-control studies. Wells G, Shea B, O'Connell D, et al. The Newcastle-Ottawa Scale (NOS) for assessing the quality of nonrandomised studies in meta-analyses. Ottawa Hospital Research Institute. http://www.ohri.ca/programs/clinical epidemiology/oxford.asp.
} 
Quality Assessment Table 1: The included cohort studies quality assessment according to the NOS

\begin{tabular}{|c|c|c|c|c|c|c|c|c|c|}
\hline \multirow[b]{2}{*}{ Studies } & \multicolumn{4}{|c|}{ Selection } & \multirow[b]{2}{*}{$\begin{array}{l}\text { Comparability } \\
\text { Comparability } \\
\text { of cohorts on } \\
\text { the basis of the } \\
\text { design or } \\
\text { analysis }\end{array}$} & \multirow[b]{2}{*}{$\begin{array}{l}\text { Assessment } \\
\text { of outcome }\end{array}$} & \multirow[b]{2}{*}{$\begin{array}{l}\text { Outcome } \\
\text { Was follow- } \\
\text { up long } \\
\text { enough for } \\
\text { outcomes to } \\
\text { occur }\end{array}$} & \multirow[b]{2}{*}{$\begin{array}{c}\text { Adequacy } \\
\text { of follow } \\
\text { up of } \\
\text { cohorts }\end{array}$} & \multirow[b]{2}{*}{ Total } \\
\hline & $\begin{array}{c}\text { Representa- } \\
\text { tiveness of } \\
\text { the exposed } \\
\text { cohort }\end{array}$ & $\begin{array}{l}\text { Selection } \\
\text { of the non- } \\
\text { exposed } \\
\text { cohort }\end{array}$ & $\begin{array}{l}\text { Ascertain- } \\
\text { ment of } \\
\text { exposure }\end{array}$ & $\begin{array}{l}\text { Demonstration } \\
\text { that outcome } \\
\text { of interest was } \\
\text { not present at } \\
\text { start of study }\end{array}$ & & & & & \\
\hline Bowers, 2006 & / & * & * & / & $\star *$ & * & * & * & 7 \\
\hline Huang, 2013 & * & * & * & * & ** & * & * & * & 9 \\
\hline Kabat, 2012 & / & * & * & / & ** & * & * & * & 7 \\
\hline Kim, 2012 & * & * & * & / & ** & * & l & * & 7 \\
\hline Liang, 2017 & / & * & * & * & ** & * & * & * & 8 \\
\hline Lin, 2014 & * & * & * & * & $* *$ & * & / & * & 8 \\
\hline Shapero, 2017 & * & * & * & * & $\star *$ & * & * & * & 9 \\
\hline Shin, 2017 & * & * & * & * & $* *$ & * & * & * & 9 \\
\hline
\end{tabular}

Quality Assessment Table 2: The included case-control studies quality assessment according to the NOS

\begin{tabular}{|c|c|c|c|c|c|c|c|c|}
\hline \multirow[b]{2}{*}{ Studies } & \multicolumn{4}{|c|}{ Selection } & \multirow{2}{*}{$\begin{array}{l}\text { Comparability } \\
\text { Comparability of } \\
\text { cases and controls on } \\
\text { the basis of the } \\
\text { design or analysis }\end{array}$} & \multicolumn{2}{|c|}{ Exposure } & \multirow[b]{2}{*}{ Total } \\
\hline & $\begin{array}{l}\text { Is the case } \\
\text { definition } \\
\text { adequate }\end{array}$ & $\begin{array}{l}\text { Representati- } \\
\text { veness of the } \\
\text { cases }\end{array}$ & $\begin{array}{l}\text { Selection } \\
\text { of } \\
\text { controls }\end{array}$ & $\begin{array}{l}\text { Definition } \\
\text { of } \\
\text { controls }\end{array}$ & & $\begin{array}{l}\text { Ascertainment } \\
\text { of exposure }\end{array}$ & $\begin{array}{l}\text { Non- } \\
\text { response } \\
\text { rate }\end{array}$ & \\
\hline Aleksandrova, 2011 & / & * & * & * & $* *$ & ** & / & 7 \\
\hline Fliss-Isakov, 2017 & * & * & / & * & ** & ** & / & 7 \\
\hline Harima, 2013 & * & * & / & * & $* *$ & ** & / & 7 \\
\hline Jeon, 2014 & * & * & * & * & ** & ** & / & 8 \\
\hline Kang, 2010 & * & * & * & * & $* *$ & ** & / & 8 \\
\hline Kontou, 2012 & * & * & * & * & ** & ** & * & 9 \\
\hline Lipka, 2013 & * & * & * & * & ** & ** & / & 8 \\
\hline Morita, 2005 & * & * & * & * & ** & ** & / & 8 \\
\hline Pelucchi, 2010 & * & * & / & * & ** & ** & * & 8 \\
\hline Pyo, 2016 & * & * & * & * & ** & ** & / & 8 \\
\hline Shen, 2010 & * & * & * & * & $* *$ & ** & * & 9 \\
\hline Stocks, 2008 & / & * & * & * & $* *$ & ** & / & 7 \\
\hline Tsilidis, 2010 & * & * & * & * & ** & $\star \star$ & I & 8 \\
\hline
\end{tabular}

Quality Assessment Table 3: The included cross-sectional studies quality assessment according to the NOS

\begin{tabular}{|c|c|c|c|c|c|c|c|c|}
\hline \multirow[b]{2}{*}{ Studies } & \multirow[b]{2}{*}{$\begin{array}{l}\text { Representati- } \\
\text { veness of the } \\
\text { sample }\end{array}$} & \multicolumn{2}{|l|}{ Selection } & \multirow[b]{2}{*}{$\begin{array}{c}\text { Non- } \\
\text { response }\end{array}$} & \multirow{2}{*}{$\begin{array}{l}\text { Comparability } \\
\text { Comparability of } \\
\text { subjects in different } \\
\text { outcome groups, } \\
\text { on the basis of the } \\
\text { design or analysis }\end{array}$} & \multicolumn{2}{|c|}{ Outcome } & \multirow[b]{2}{*}{ Total } \\
\hline & & $\begin{array}{l}\text { Ascertainment } \\
\text { of the } \\
\text { exposure (risk } \\
\text { factor) }\end{array}$ & $\begin{array}{l}\text { Sample } \\
\text { size }\end{array}$ & & & $\begin{array}{l}\text { Assessment } \\
\text { of the } \\
\text { outcome }\end{array}$ & $\begin{array}{c}\text { Statistical } \\
\text { test }\end{array}$ & \\
\hline Hong, 2010 & * & $* *$ & * & I & $* *$ & * & * & 8 \\
\hline Hong, 2015 & / & ** & * & l & $* *$ & * & * & 7 \\
\hline $\mathrm{Hu}, 2011$ & * & $* *$ & * & I & $\star *$ & * & * & 8 \\
\hline Hwang, 2010 & * & $* *$ & * & / & $* *$ & * & * & 8 \\
\hline Jung, 2014 & * & ** & * & / & $* \star$ & * & * & 8 \\
\hline Kim, 2007 & * & ** & * & / & $\star *$ & * & * & 8 \\
\hline Lee, 2014 & * & $* *$ & * & / & $* *$ & * & * & 8 \\
\hline Oh, 2008 & * & $* *$ & / & / & $* *$ & * & * & 7 \\
\hline Sato, 2011 & * & $* *$ & / & / & $* *$ & * & * & 7 \\
\hline Yang, 2016 & * & ** & / & / & $\star \star$ & * & * & 7 \\
\hline
\end{tabular}

